\title{
Volume conversion factors for wood measured in Ontario and Quebec
}

\section{SEREF ALEMDAG}

Forest Management Institute

Department of Fisheries and Forestry

Ottawa, Ontario

Ontario and Quebec employ different procedures for determining wood volumes, both in cubic feet and board feet. These differences present management problems to wood-using companies which rely on both provinces for their supply of raw material. In most cases, Ontario rules record less volume for a given sample than Quebec rules. Equations have been produced which provide a basis for effective conversion.

\section{Necessity for conversion}

Standard measuring procedures for obtaining wood volumes are firmly established within Ontario and Quebec, but the two systems differ on a number of fundamental points. This situation presents practical problems for any wood-utilizing plant which draws its raw material from both provinces.

A theoretical comparison of the official log scaling rules in Ontario and Quebec (Ontario Department of Lands and Forests 1965 and 1967, Quebec Department of Lands and Forests 1967) has already been made and an approach to developing volume conversion factors discussed ${ }^{1}$. The present article introduces conversion factors which apply to current scaling practices. The procedures for deductions of cull and defect are not considered, because the complexity of the rules governing these factors prevents the establishment of firm and constant relationships between corresponding deductions.

\section{Source of differences}

In Ontario and Quebec both cubic-foot and boardfoot measurements are used. Where cubic-foot scaling is employed volume differences arise because of varying diameter and length definitions and of different volume calculating formulae. For boardfoot scaling, differences in volume between the provinces are due solely to the formulae used for calculating volume. A comparison of these scaling systems is provided in Table 1.

\section{Development of conversion factors}

For cubic-foot scaling, the volume conversion factor equations were developed by separately considering $1 /$ diameter ranges, 2 / location of diameter measurements for logs of different length categories, and 3 / volume calculating formulae as applied to different length classes; in each case it was assumed that the other variables remain constant. Each one of the final conversion factors is a product of the resulting factors of these analyses ${ }^{1}$. However,

${ }^{1}$ ALEMDAG, I. S. 1969. Converting Ontario and Quebec wood volumes. Canada Dep. Fish. Forest., Forest. Branch, Forest Man. Inst. Intern. Rep. FMR-14. for the board-foot scaling, only the volume calculating formulae were compared since all other variables remain the same.

In every comparison only the volumes of logs, calculated by the two measuring systems, were employed. Comparing diameters directly, without considering volume calculations, would not give the same answer. But within the idea of forming corresponding diameters, there could be alternatives on which the volume calculations would be based. Some of these alternatives are summarized below. For the sake of the argument, the conversion of Quebec volume to Ontario volume is considered (Figure 1), expressing the diameters in inches. If a diameter D of the Quebec range from 9.50 to 10.50 inches is taken, the total volume of 100 logs of this diameter by Quebec scaling will have an equivalent volume of the logs at the diameters of stated alternatives as shown in Table 2.

The first alternative seemed to be the most logical one and was therefore followed in this paper for establishing the conversion factors. However, the others could also be taken into consideration. Along with the present analyses, the second one was also worked-out and it was found that the differences between the conversion factors of the two analyses were negligibly small.

\section{Volume conversion factors}

In the following equations, $D$ represents the largeend diameter and $d$ the small-end diameter. The $p$ conversion factors represent the ratio of Ontario volume to Quebec volume. The diameters $D$ or $d$ in these equations are Quebec recorded diameters in inches. These factors are the ones to be used in converting Quebec volume to Ontario volume. The $p^{\prime}$ conversion factors represent the ratio of Quebec

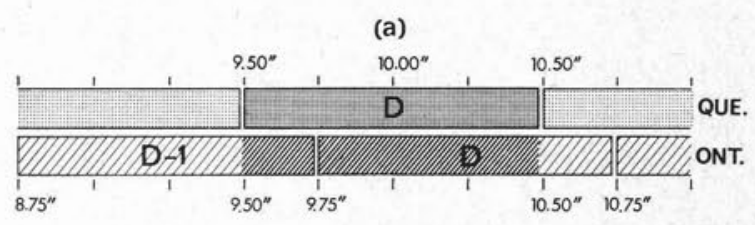

(b)

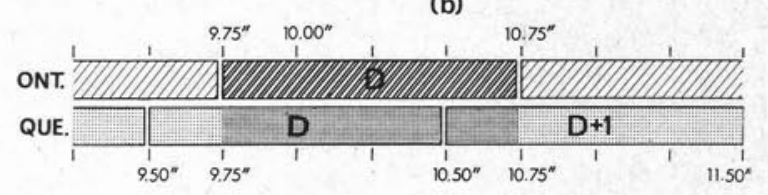

Fig. 1. Illustration of the corresponding diameter ranges of D of Ontario and Quebec, (a) when converting Quebec volume to Ontario volume and ( $b$ ) when converting Ontario volume to Quebec volume. 
volume to Ontario volume. The diameters $D$ or $d$ in these equations are Ontario recorded diameters in inches. These factors are the ones to be used in converting Ontario volume to Quebec volume. Log lengths are assumed to be equal within each particular category. Because of the shifted diameters in cubic-foot scaling, one conversion factor is not the reciprocal of its corresponding conversion factor.

Before giving the final conversion factors below, an introductory example of the results of diameter comparisons of cubic-foot scaling is thought to be worthwhile. Thus, to find the ratio of an Ontario to a Quebec volume it is necessary to compare the total partial volumes of two logs scaled by Ontario standards, one having 75 per cent of the volume of a diameter $D$ and the other one having 25 per cent of the volume of a diameter D-1, with the volume of one log of diameter D determined by Quebec scaling regulations. The ratio of these two volumes is ex- pressed as the ratio of the basal areas. When expressed by the large-end diameter $D$, the ratio is

$$
\frac{D^{2}-0.5 D+0.25}{D^{2}}
$$

and when expressed by the small-end diameter $d$, the ratio is

$$
\frac{d^{2}-0.5 d+0.25}{d^{2}}
$$

In the situation where a log is measured at both ends, it then becomes necessary to average ratios of (1) and (2), with the following result:

$\frac{D^{2} d^{2}-0.25 D d^{2}-0.25 D^{2} d+0.125 D^{2}+0.125 d^{2}}{D^{2} d^{2}}$

In the event of a log being measured in the first instance at one end only, and in the second instance at both ends, then the average of (1) and (3), or (2) and (3), should be taken.

TABLI: 1. Standards followed in scaling the logs in Ontario and Quebec

Log length category
Diameter range standard
Diameter measuring location
Volume calculating formula

Cubic-foot scaling

Up to $10 \mathrm{ft} 6$ in. ONT.

Froni an inch and three quarters to the next inch and three quarters, recording point being at the first quarter of the range.

QUE. From an inch and a half to the next inch and a half, recording point being at the mid-

\begin{tabular}{|c|c|c|c|c|}
\hline $\begin{array}{l}\text { From } 10 \mathrm{ft} 6 \text { in. } \\
\text { to } \\
18 \mathrm{ft} 8 \mathrm{in} .\end{array}$ & $\begin{array}{l}\text { ONT. } \\
\text { QUE. }\end{array}$ & $\begin{array}{l}\text { Same as above } \\
\text { Same as above }\end{array}$ & $\begin{array}{l}\text { One end of the log } \\
\text { Both ends of the log }\end{array}$ & $\begin{array}{l}\text { Cylinder } \\
\text { Smalian's }\end{array}$ \\
\hline \multirow[t]{2}{*}{ Over $18 \mathrm{ft} .8$ in. } & ONT. & Same as above & Both ends of the $\log$ & Huber's modification \\
\hline & QUE. & Same as above & Both ends of the log & Smalian's \\
\hline \multirow[t]{2}{*}{$\begin{array}{l}\text { Board-foot scaling } \\
\text { Up to } 18 \mathrm{ft}\end{array}$} & ONT. & $\begin{array}{l}\text { From an inch and three quarters to the next } \\
\text { inch and three quarters, recording point } \\
\text { being at the first quarter of the range. }\end{array}$ & Small-end of the log & Ontario Log Rule \\
\hline & QUE. & Same as above & Small-end of the log & Roy Log Rule \\
\hline \multirow{2}{*}{$\begin{array}{l}\text { Between } 18 \mathrm{ft} \\
\text { and } 20 \mathrm{ft}\end{array}$} & ONT. & No application & No application & No application \\
\hline & QUE. & Same as above & Same as above & Same as above \\
\hline
\end{tabular}
dle of the range.

TABLE 2. Alternative ways of forming diameters for the comparison of Quebec volume to Ontario volume

\begin{tabular}{|c|c|c|c|c|c|c|}
\hline Alternative & $\begin{array}{c}\text { Form of } \\
\text { diameter } \\
\text { distribution }\end{array}$ & $\begin{array}{l}\text { Ways of } \\
\text { diameter } \\
\text { measurement }\end{array}$ & $\begin{array}{l}\text { Number } \\
\text { of logs }\end{array}$ & $\begin{array}{c}\text { Diameter } \\
\text { coverage } \\
\text { (inches) }\end{array}$ & $\begin{array}{c}\text { Formed } \\
\text { diameter } \\
\text { (inches) }\end{array}$ & $\begin{array}{l}\text { Corresponding } \\
\text { volume } \\
\text { (cu ft) }\end{array}$ \\
\hline 1 & normal & $\begin{array}{l}\text { actual } \\
\text { scaling }\end{array}$ & $\begin{array}{l}25 \\
75\end{array}$ & $\begin{array}{l}9.50 \text { to } 9.75 \\
9.75 \text { to } 10.50\end{array}$ & $\begin{array}{l}\mathrm{D}-1 \\
\mathrm{D}\end{array}$ & $\begin{array}{l}25 x \text { vol of a }(D-1) \log \\
75 x \text { vol of a (D) } \log \end{array}$ \\
\hline 2 & non-normal & $\begin{array}{l}\text { actual } \\
\text { scaling }\end{array}$ & $\begin{array}{r}50 \\
50\end{array}$ & $\begin{array}{l}9.50 \text { to } 9.75 \\
9.75 \text { to } 10.50\end{array}$ & $\begin{array}{l}\mathrm{D}-1 \\
\mathrm{D}\end{array}$ & $\begin{array}{l}50 x \text { vol of a }(D-1) \log \\
50 x \text { vol of a (D) log }\end{array}$ \\
\hline 3 & non-normal & averaging & $\begin{array}{l}50 \\
50\end{array}$ & $\begin{array}{l}9.50 \text { to } 9.75 \\
9.75 \text { to } 10.50\end{array}$ & $\begin{array}{l}\mathrm{D}-0.375 \\
\mathrm{D}+0.125\end{array}$ & $\begin{array}{l}50 \mathrm{x} \text { vol of a }(\mathrm{D}-0.375) \log \\
50 \mathrm{x} \text { vol of a }(\mathrm{D}+0.125) \log \end{array}$ \\
\hline 4 & normal & $\begin{array}{l}\text { mid-point } \\
\text { calculating }\end{array}$ & 100 & 9.75 to 10.75 & $\mathrm{D}+0.25$ & $100 \mathrm{x}$ vol of a $(\mathrm{D}+0.25) \log$ \\
\hline 5 & non-normal & fractioning & $\begin{array}{l}50 \\
50\end{array}$ & $\begin{array}{l}8.75 \text { to } 9.75 \\
9.75 \text { to } 10.75\end{array}$ & $\begin{array}{l}\text { (D-1) }-0.25+25 \% \times 1 \\
\text { (D) }-0.25+75 \% \times 1\end{array}$ & $\begin{array}{l}50 x \text { vol of a }(D-1) \log \\
50 x \text { vol of } a(D+0.5) \log \end{array}$ \\
\hline
\end{tabular}

Ontario scaling 
Cubic-foot scaling. 1/ When large-end diameter is recorded both in Ontario and Quebec for materials up to 10 feet 6 inches in length,

$$
p_{1}=\frac{D^{2}-0.5 D+0.25}{D^{2}}
$$

and

$$
p^{\prime}{ }_{1}=\frac{D^{2}+0.5 D+0.25}{D^{2}}
$$

When small-end diameter is recorded both in Ontario and Quebec for materials up to 10 feet 6 inches in length,

$$
p_{2}=\frac{d^{2}-0.5 d+0.25}{d^{2}}
$$

and

$$
p_{2}^{\prime}=\frac{d^{2}+0.5 d+0.25}{d^{2}}
$$

If large- and small-end diameters are all recorded on one side of a pile of logs for materials up to 10 feet 6 inches in length,

$$
p_{3}=\frac{p_{1}+p_{2}}{2}(8) \text { and } \quad p_{3}^{\prime}=\frac{p_{1}^{\prime}+p_{2}^{\prime}}{2}
$$

2/ When large-end diameter is recorded in Ontario and both end diameters in Quebec for materials from 10 feet 6 inches to 18 feet 8 inches in length,

$$
p_{4}=\frac{2 D^{2} d^{2}-0.75 D d^{2}-0.25 D^{2} d+}{0.125 D^{2}+0.375 d^{2}}
$$

and

$$
p_{4}^{\prime}=\frac{\begin{array}{c}
\left(D^{2}+d^{2}\right)\left(2 D^{2} d^{2}+0.25 D^{2} d+\right. \\
\left.0.75 D d^{2}+0.125 D^{2}+0.375 d^{2}\right)
\end{array}}{4 D^{4} d^{2}}
$$

The recording of small-end diameter in Ontario and both end diameters in Quebec for materials from 10 feet 6 inches to 18 feet 8 inches in length results in,

$$
p_{5}=\frac{2 D^{2} d^{2}-0.25 D d^{2}-0.75 D^{2} d+}{0.375 D^{2}+0.125 d^{2}}
$$

and

$$
p^{1}{ }_{\dot{ }}=\frac{\left(D^{2}+d^{2}\right)\left(2 D^{2} d^{2}+0.75 D^{2} d+0.25 D d^{2}+\right.}{\left.0.375 D^{2}+0.125 d^{2}\right)}
$$

If large- and small-end diameters are all recorded on one side of a pile of logs in Ontario and on both sides in Quebec for materials from 10 feet 6 inches to 18 feet 8 inches in length,

$$
p_{6}=\frac{p_{4}+p_{5}}{2}(14) \text { and } p_{6}^{\prime}=\frac{p_{4}^{\prime}+p_{5}^{\prime}}{2}
$$

3/ When both end diameters are recorded in Ontario and Quebec for materials over 18 feet 8 inches in length,

$$
p_{7}=\frac{\left(D^{2} d^{2}-0.25 D d^{2}-0.25 D^{2} d+\right.}{\left.0.125 D^{2}+0.125 d^{2}\right)(D+d)^{2}}
$$

and

$$
p_{\tau}^{\prime}=\frac{\left(D^{2}+d^{2}\right)\left(2 D^{2} d^{2}+0.5 D^{2} d+0.5 D d^{2}+\right.}{\left.0.25 D^{2}+0.25 d^{2}\right)}
$$

Board-foot scaling. For materials up to 18 feet in

\begin{tabular}{|c|c|c|c|c|c|c|c|}
\hline & $d$ & $p_{1}$ & $\boldsymbol{p}_{2}$ & $p_{4}$ & $p_{5}$ & $\boldsymbol{p}_{7}$ & $\boldsymbol{p}_{8}$ \\
\hline 5 & $\begin{array}{r}4 \\
9 \\
14 \\
19 \\
24 \\
29\end{array}$ & & & & & & \\
\hline & $\begin{array}{r}3 \\
8 \\
13 \\
18 \\
23 \\
28\end{array}$ & $\begin{array}{l}0.95250 \\
0.96778 \\
0.97562 \\
0.98040 \\
0.98361\end{array}$ & $\begin{array}{l}0.94141 \\
0.96302 \\
0.97299 \\
0.97873 \\
0.98246\end{array}$ & & $\begin{array}{l}0.73692 \\
0.82716 \\
0.87145 \\
0.89770 \\
0.91505\end{array}$ & $\begin{array}{l}0.93540 \\
0.96050 \\
0.97162 \\
0.97787 \\
0.98187\end{array}$ & \\
\hline
\end{tabular}
length,

$$
p_{8}=\frac{5}{3} \cdot \frac{0.55 d^{2}-1.2 d}{(d-1)^{2}}
$$

and

$$
p^{\prime} s=\frac{3}{5} \cdot \frac{(d-1)^{2}}{0.55 d^{2}-1.2 \mathrm{~d}}
$$

Using the above equations, conversion factors could be calculated for various combinations of $D$ and $d$. An example, for $p$ values is presented in Table 3. With the exception of $p_{4}$ it will be noted that Ontario registers less volume than Quebec.

TABLE 3. Volume conversion factors for some diameter combinations to be used in converting Quebec volume to Ontario volume

\section{Recommended applications}

The use of these volume conversion factors is restricted by the fact that the values are limited to specific size classes or groupings of diameters and lengths, which rarely occurs in practice. Nevertheless, for practical applications in the industry that has to exchange wood, compute its productivity, compare union agreement rates, etc., the theory may be adapted in several ways. It will be noted from the $p$ values for small diameter logs that the percentage difference in volume, either in cubic feet or board feet, is relatively high. When a large amount of material such as pulpwood is involved, this will mean substantial volume differences.

For specific cases the conversion equations may be used individually. Where more general use is envisaged, tables could be prepared showing cubicfoot conversion factors by diameter classes. Computers could also be employed where the volume of 
work suggests that this technique would prove more economical.

Another approach that may be useful is to establish the average large- and small-end diameters together with the average log length in a pile and, with the appropriate equation, derive an average conversion factor. Alternatively, a more precise conversion factor for a pile could be obtained by establishing the average diameter, diameter range, and average length of its logs together with tapers and diameter distribution by classes. After calculating conversion factors for each diameter class and taking the weighed average according to frequency distribution, final volume conversion factors could be produced.

TABLE 4. Average volume conversion factors by diameter classes, (a) for converting Quebec volume to Ontario volume and (b) for converting Ontario volume to Quebec volume

\begin{tabular}{|c|c|c|c|c|c|}
\hline \multirow{2}{*}{$\begin{array}{c}\text { Diameter } \\
\text { class } \\
\text { (inches) }\end{array}$} & \multicolumn{4}{|c|}{$\begin{array}{l}\text { Cubic-foot scaling } \\
\text { Length }\end{array}$} & \multirow{2}{*}{$\begin{array}{l}\text { Board- } \\
\text { foot } \\
\text { scaling }\end{array}$} \\
\hline & $10^{2}$ & $\begin{array}{l}\mathrm{p} \text { to } \\
6 \mathrm{in} .\end{array}$ & $\begin{array}{l}10 \mathrm{ft} 6 \text { in. } \\
\text { to } \\
18 \mathrm{ft} 8 \text { in. }\end{array}$ & $\begin{array}{c}\text { over } \\
18 \mathrm{ft} 8 \text { in. }\end{array}$ & \\
\hline $5-10$ & $\begin{array}{l}\text { (a) } \\
\text { (b) }\end{array}$ & $\begin{array}{l}0.930 \\
1.081\end{array}$ & $\begin{array}{l}0.930 \\
1.147\end{array}$ & $\begin{array}{l}0.917 \\
1.097\end{array}$ & $\begin{array}{l}0.865 \\
1.156\end{array}$ \\
\hline $10-20$ & $\begin{array}{l}\text { (a) } \\
\text { (b) }\end{array}$ & $\begin{array}{l}0.966 \\
1.036\end{array}$ & $\begin{array}{l}0.966 \\
1.050\end{array}$ & $\begin{array}{l}0.963 \\
1.040\end{array}$ & $\begin{array}{l}0.900 \\
1.112\end{array}$ \\
\hline $20-30$ & $\begin{array}{l}\text { (a) } \\
\text { (b) }\end{array}$ & $\begin{array}{l}0.980 \\
1.021\end{array}$ & $\begin{array}{l}0.980 \\
1.026\end{array}$ & $\begin{array}{l}0.979 \\
1.022\end{array}$ & $\begin{array}{l}0.908 \\
1.102\end{array}$ \\
\hline
\end{tabular}

Finally, it may be of practical value to establish average conversion factor values for certain diameter classes in relation to length categories for application to piles containing materials of mixed length and diameter. The results given in Table 4 allow overall application.

Facteurs de conversion pour les volumes ligneux mesurés en Ontario et au Québec

L'Ontario et le Québec se servent de différentes méthodes d'évaluation du volume des bois, soit en pieds cubes ou en pieds mesures de planches (p.m.p.). Celles-ci présentent de réels problèmes d'administration pour les compagnies qui utilisent le matériel brut en provenance des deux provinces.

Dans la majorité des cas, les règles en usage en Ontario accordent pour un même échantillon, moins de volume que celles en vigueur au Québec.

Des équations ont été développées servant de base à une conversion adéquate.

\footnotetext{
References

ONTARIO DEPARTMENT OF LANDS AND FORESTS. 1965 Manual of scaling instructions. Parts I and II, 80 p. and $111 \mathrm{p}$. 1967. Scaling procedures. Circular T. 15-8. 2 p. QUEBEC DEPARTMENT OF LANDS AND FORESTS. 1967. Official regulations and instructions concerning the scaling of wood cut on Crown Lands. $86 \mathrm{p}$.
}

\section{CANADIAN JOURNAL OF FOREST RESEARCH}

The Canadian Journal of Forest Research will be published quarterly starting March, 1971. This Journal, published by the National Research Council, will contain technical, scientific, and informational articles on all types of forest research in Canada.

This valuable magazine is available to members of the Canadian Institute of Forestry - Institut Forestier du Canada for $\$ 2.50$ per yearly subscription. This price is one half the normal subscription rate.

Please fill in the coupon below and forward it together with your cheque or money order for $\$ 2.50$ for each subscription.

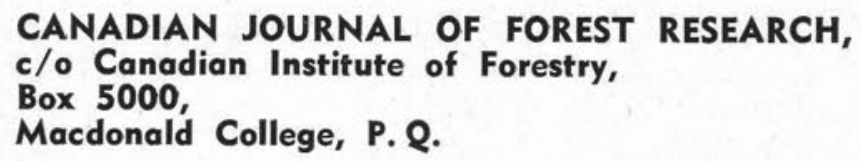

CANADIAN JOURNAL OF FOREST RESEARCH, c/O Canadian Institute of Forestry,

Box 5000,

Macdonald College, P. Q.

Please place my name on the subscription list for the Canadian Journal of Forest Research. Enclosed is my cheque / money order for $\$ 2.50$.

\section{(PLEASE PRINT)}

Name:

Address:

Signature: 